\title{
SINTESIS DAN KARAKTERISASI NANOHERBAL EKSTRAK ETANOL KAYU SECANG (Caesalpinia sappan L.)
}

\author{
Nabella Dwitarani, Rafiqi Rajauddin Amin, Titik Mardiyanti Sofyah, \\ Disfanya Nichelen Ramadhani, Suyatno Sutoyo* \\ Jurusan Kimia, Fakultas Matematika dan Ilmu Pengetahuan Alam, Universitas Negeri Surabaya \\ *email : suyatno@unesa.ac.id
}

Received 24 Oktober 2021

Accepted 3 Desember 2021

\begin{abstract}
Abstrak
Tanaman secang (Caesalpinia sappan L.) merupakan salah satu tanaman obat Indonesia yang sudah banyak dimanfaatkan oleh masyarakat. Ekstrak etanol kayu secang diketahui memiliki aktivitas antioksidan yang kuat. Sediaan dalam bentuk ekstrak memiliki bioavailabilitas yang rendah karena rendahnya kelarutan dalam air dan tidak stabil terhadap faktor lingkungan. Salah satu upaya untuk mengatasi masalah tersebut yaitu dengan memformulasikan ke dalam sediaan nanopartikel. Penelitian ini bertujuan untuk melakukan sintesis dan karakterisasi nanoherbal ekstrak etanol kayu secang menggunakan metode gelasi ionik. Ekstrak kayu secang diformulasi dalam bentuk nanopartikel dengan perbandingan kitosan-Na-TPP yaitu 1:1 (F1), 3:2 (F2), dan 2:1 (F3). Nanoherbal hasil sintesis dikarakterisasi menggunakan zetasizer nano untuk menentukan ukuran partikel dan potensial zeta serta spektroskopi infra merah (FTIR). Hasil penelitian menunjukkan nanoherbal F1 memiliki ukuran partikel yang memenuhi syarat sebagai nanopartikel $(900,8$ $\mathrm{nm}$ ) dan memiliki potensial zeta sebesar $+529,6 \mathrm{mV}$. Spektrum IR mendukung terjadinya nanopartikel herbal yang ditunjukkan oleh pergeseran bilangan gelombang vibrasi ulur gugus - OH $\left(3297 \mathrm{~cm}^{-1} \mathrm{ke} 3197 \mathrm{~cm}^{-1}\right)$, vibrasi tekuk gugus -NH $\left(1582 \mathrm{~cm}^{-1} \mathrm{ke} 1557 \mathrm{~cm}^{-1}\right)$, serta munculnya puncak vibrasi gugus fosfat pada bilangan gelombang $1071 \mathrm{~cm}^{-1}$.
\end{abstract}

Kata kunci: Kayu secang, nanoherbal, kitosan, Na-TPP, gelasi ionik

\begin{abstract}
Secang plant (Caesalpinia sappan L.) is one of the Indonesian medicinal plant that had been widely used by people. The ethanol extract of secang wood is well-known for its antioxidant activity. Preparations in extracts have poor bioavailability due to low solubility and unstable to environmental factors. One of the efforts to overcome this problem is to formulate it into nanoparticle preparations. This study aims to synthesize and characterize the ethanol extract of Secang wood nanoherbs using the ionic gelation method. Secang wood extract is formulated in the form of nanoparticles with ratio of chitosan:Na-TPP, namely 1:1 (F1), 3:2 $(\mathrm{F} 2)$, and 2:1 (F3). The results of nanoherbs were characterized using a zetasizer to determine the particle size and zeta potential and infrared spectroscopy (FTIR). The results showed that the nanoherb F1 had a particle size that met the requirements of nanoparticles $(900,8 \mathrm{~nm})$ and zeta potential of $+529,6 \mathrm{mV}$. The IR spectrum supports the occurrence of herbal nanoparticles as indicated by a shift in the wavenumber of the $-\mathrm{OH}$ group $\left(3297 \mathrm{~cm}^{-}\right.$ ${ }^{1}$ to $\left.3197 \mathrm{~cm}^{-1}\right)$, the $-\mathrm{NH}$ group $\left(1582 \mathrm{~cm}^{-1}\right.$ to $\left.1557 \mathrm{~cm}^{-1}\right)$, and the appearance of a vibrational peak of the phosphate group at a wavenumber of $1071 \mathrm{~cm}^{-1}$.
\end{abstract}

Keywords: Secang wood, nanoherbs, chitosan, Na-TPP, ionic gelation 


\section{Pendahuluan}

Salah satu tanaman obat yang telah banyak dimanfaatkan oleh masyarakat Indonesia adalah tanaman secang (Caesalpinia sappan L.). Kayu secang mempunyai aktivitas antioksidan yang lebih kuat dibandingkan dengan antioksidan sintetis seperti asam beta hidroksi dan butil hidroksi toluena (Sugiyanto, et al., 2013).

Kusmiati dan Priadi (2014) menyebutkan bahwa kayu secang memiliki kandungan senyawa aktif berupa flavonoid, alkaloid, saponin, tanin, fenolik, dan brazilin. Kandungan flavonoid, alkaloid, dan saponin dalam kayu secang berguna sebagai antioksidan, antifungi, dan antiinflamasi, serta tanin bersifat sebagai antibakteri dan antivirus. Terdapat 5 jenis flavonoid dalam kayu secang diantaranya yaitu brazilin, brazilein, sappancalchone, chalcone, sappanin, dan 3'-O-metilbrazilin yang berguna sebagai antioksidan primer maupun sekunder (Rina, 2013).

Selama ini, pemanfaatan herbal untuk dikonsumsi berasal dari ekstrak tanaman. Kelemahan sediaan ekstrak yaitu kelarutannya dalam air rendah sehingga bioavailabilitasnya rendah serta sifat fungsionalnya dapat menurun akibat proses pengolahan hingga lamanya waktu penyimpanan.

Salah satu upaya untuk meningkatkan kelarutan dan menjaga sifat fungsional ekstrak yaitu dengan memformulasikan ekstrak dalam sediaan nanopartikel (Ardila, et al., 2017). Nanopartikel merupakan suatu partikel dengan rata-rata ukuran diameter partikel yaitu 1-1000 nm (Mohanraj \& Chen, 2006). Kelebihan nanopartikel yaitu memiliki karakter fisik yang berbeda daripada partikel yang memiliki ukuran lebih besar diantaranya yaitu menaikkan kapasitas penghantaran senyawa aktif (Martien, et al., 2012), menambah kelarutan senyawa, serta meningkatkan absorbsi partikel (Rismana, et al., 2013).
Nanopartikel dari herbal (nanoherbal) dapat dibuat dengan beberapa metode, salah satunya yaitu metode gelasi ionik. Kelebihan metode ini yaitu proses dikontrol dengan mudah serta tidak memerlukan pelarut organik (Mardliyanti, et al., 2012).

Metode gelasi ionik dilakukan dengan mencampur polimer yang bersifat polikation dengan polianion. Kitosan merupakan salah satu polimer polikation yang biasa dimanfaatkan karena bersifat biodegradable, biocompatible, tidak toksik, dan mudah dikonversi secara kimia. Sementara itu polianion yang biasa digunakan yaitu natrium tripolifosfat $(\mathrm{Na}-$ TPP) karena mampu menjadi pengikat silang yang baik. Na-TPP akan memperkuat kekuatan mekanik kitosan karena mempunyai muatan negatif dengan kerapatan yang tinggi sehingga interaksi dengan polikation kitosan meningkat (Kaban, et al., 2006; Shu \& Zhu, 2002).

Hasil penelitian Luntungan (2017) menyatakan bahwa aktivitas antioksidan pada nanopartikel mengalami peningkatan karena biopolimer alami kitosan mampu mengubah secara kimia. Hasil penelitian lain juga menyebutkan bahwa kitosan yang digunakan untuk pembentukan nanopartikel ekstrak temulawak dapat meningkatkan aktivitas antibakteri (Syarmalina, et al., 2019).

Penelitian terkait sintesis nanoherbal dari ekstrak etanol kayu secang belum pernah dilaporkan. Oleh karena itu artikel ini melaporkan sintesis nanoherbal dari ekstrak etanol kayu secang dengan metode gelasi ionik yang dilanjutkan karakterisasi nanoherbal yang terbentuk.

\section{Metode Penelitian}

\section{Alat dan bahan}

Peralatan yang digunakan dalam penelitian ini yaitu seperangkat alat maserasi, rotary vacuum evaporator (Buchi R-300), oven (Heraeus ST-5042), pompa vakum, freeze dryer (CHRIST Alpha 1-2 LDplus), corong Buchner, neraca analitik (Advanturer Ohaus), lemari 
pendingin, magnetic stirrer (Heidolph MR Hei-Standard), Dynamic Light Scattering Zetasizer Nano (Malvern), Spektrometer FT-IR (PerkinElmer), dan peralatan gelas. Bahan yang digunakan yaitu serbuk kayu secang, etanol p.a. (Merck), aquabides, etanol teknis (96\%), kitosan (Himedia), asam asetat glasial, natrium tripolifosfat (Na-TPP), dan tween-80 (Merck).

\section{Ekstraksi Sampel}

Pembuatan ekstrak etanol kayu secang dilakukan dengan cara maserasi menggunakan pelarut etanol teknis (96\%). Serbuk kering kayu secang (C. sappan L.) sebanyak 500 gram dimaserasi dengan etanol teknis (96\%) dan ditutup rapat dalam waktu 24 jam pada suhu ruang. Hasil maserasi disaring dengan corong Buchner dan pompa vakum. Residu hasil penyaringan dimaserasi kembali sebanyak dua kali dengan prosedur yang sama. Ekstrak etanol yang diperoleh dipekatkan dengan rotavapor, dilanjutkan pengeringan dengan freeze dryer selama 8 jam sehingga diperoleh ekstrak etanol kayu secang padat.

\section{Sintesis Nanoherbal}

Sintesis nanoherbal dilakukan menggunakan metode gelasi ionik dengan kitosan sebagai biopolimer kation dan $\mathrm{Na}-$ TPP sebagi anion multivalent.

Larutan kitosan dibuat dengan 3 variasi konsentrasi sebesar 0,50; 0,75; dan 1,00\%. Sebanyak 0,$50 ; 0,75$; dan 1,00 gram kitosan ditimbang lalu dilarutkan menggunakan larutan asam asetat $5 \%(\mathrm{v} / \mathrm{v})$ sampai $100 \mathrm{~mL}$ dan dihomogenkan menggunakan magnetic stirrer (Pakki, et al., 2016).

Larutan Na-TPP menggunakan 3 variasi volume yaitu 20,30 , dan $40 \mathrm{~mL}$ dengan konsentrasi $0,5 \%$. Na-TPP ditimbang sebanyak 0,$10 ; 0,15$; dan 0,20 gram. Selanjutnya ketiga larutan dilarutkan menggunakan aquabides sampai 20, 30, dan $40 \mathrm{~mL}$ lalu dihomogenkan menggunakan magnetic stirrer (Pakki, et al., 2016).

Nanoherbal ekstrak etanol kayu secang dibuat dengan 3 formulasi yaitu F1, F2, dan F3. Larutan kitosan dengan variasi konsentrasi 0,$50 ; 0,75$; dan $1,00 \%$ sebanyak $100 \mathrm{~mL}$ dimasukkan ke dalam Erlenmeyer. Kemudian tween-80 sebanyak $1 \mathrm{~mL}$ ditambahkan ke dalam masing-masing larutan kitosan dan diaduk dengan magnetic stirrer dalam waktu 10 menit pada kecepatan 1000 rpm. Selanjutnya ditambahkan 0,1 gram ekstrak etanol kayu secang pada setiap Erlenmeyer dan diaduk dengan magnetic stirrer dalam waktu 30 menit pada kecepatan $1400 \mathrm{rpm}$. Lalu sebanyak $20 \mathrm{~mL}$ larutan Na-TPP $0,5 \%$ dimasukkan pada $\mathrm{F} 1,30 \mathrm{~mL}$ pada $\mathrm{F} 2$, dan $40 \mathrm{~mL}$ pada $\mathrm{F} 3$, kemudian diaduk dengan magnetic stirrer dalam waktu 120 menit pada kecepatan $1400 \mathrm{rpm}$. Hasil yang didapatkan selanjutnya didiamkan dengan waktu 24 jam (Pakki, et al., 2016).

Tabel 1. Formula nanoherbal ekstrak etanol kayu secang

\begin{tabular}{lccc}
\hline \multicolumn{1}{c}{ Bahan } & F1 & F2 & F3 \\
\hline Ekstrak Etanol Kayu Secang & 0,1 gram & 0,1 gram & 0,1 gram \\
Larutan Kitosan 0,50\% & $100 \mathrm{~mL}$ & - & - \\
Larutan Kitosan 0,75\% & - & $100 \mathrm{~mL}$ & - \\
Larutan Kitosan 1,00\% & - & - & $100 \mathrm{~mL}$ \\
Larutan Na-TPP 0,5\% & $20 \mathrm{~mL}$ & $30 \mathrm{~mL}$ & $40 \mathrm{~mL}$ \\
Tween-80 & $1 \mathrm{~mL}$ & $1 \mathrm{~mL}$ & $1 \mathrm{~mL}$ \\
\hline
\end{tabular}

Karakterisasi Nanoherbal

Nanoherbal ekstrak etanol kayu secang hasil sintesis dikarakterisasi dengan Zetasizer Nano untuk menentukan ukuran partikel dan potensial zeta serta dengan spektrometer FTIR untuk menentukan gugus fungsi. 


\section{Hasil dan Pembahasan}

\section{Ekstraksi Sampel}

Serbuk kering kayu secang (C. sappan L.) sebanyak 500 gram dimaserasi dengan pelarut etanol teknis dalam waktu 24 jam pada suhu ruang. Hasil maserasi disaring dengan vacuum dan corong Buchner lalu dilakukan remaserasi sebanyak dua kali pada residu. Ekstrak etanol kayu secang yang diperoleh dipekatkan dengan rotavapor, dilanjutkan pengeringan dengan freeze dryer selama 8 jam sehingga diperoleh ekstrak etanol kayu secang padat berwarna merah tua sebanyak 21,745 gram.

\section{Sintesis Nanoherbal}

Sintesis nanoherbal ekstrak etanol kayu secang dilakukan dengan metode gelasi ionik. Prinsip pembentukan nanoherbal dengan metode gelasi ionik adalah pembentukan ikatan silang polielektrolit dengan pasangan ion multivalennya (Park \& Yeo, 2007). Dalam penelitian ini ikatan silang terjadi akibat interaksi eletrostatik antara gugus amina $\left(\mathrm{NH}_{3}{ }^{+}\right)$pada kitosan dengan gugus bermuatan negatif $\left(\mathrm{PO}_{4}{ }^{3-}\right)$ dari Na-TPP. Pembentukan ikatan silang memperbesar kekuatan mekanis partikel yang terbentuk (Putri, et al., 2018).

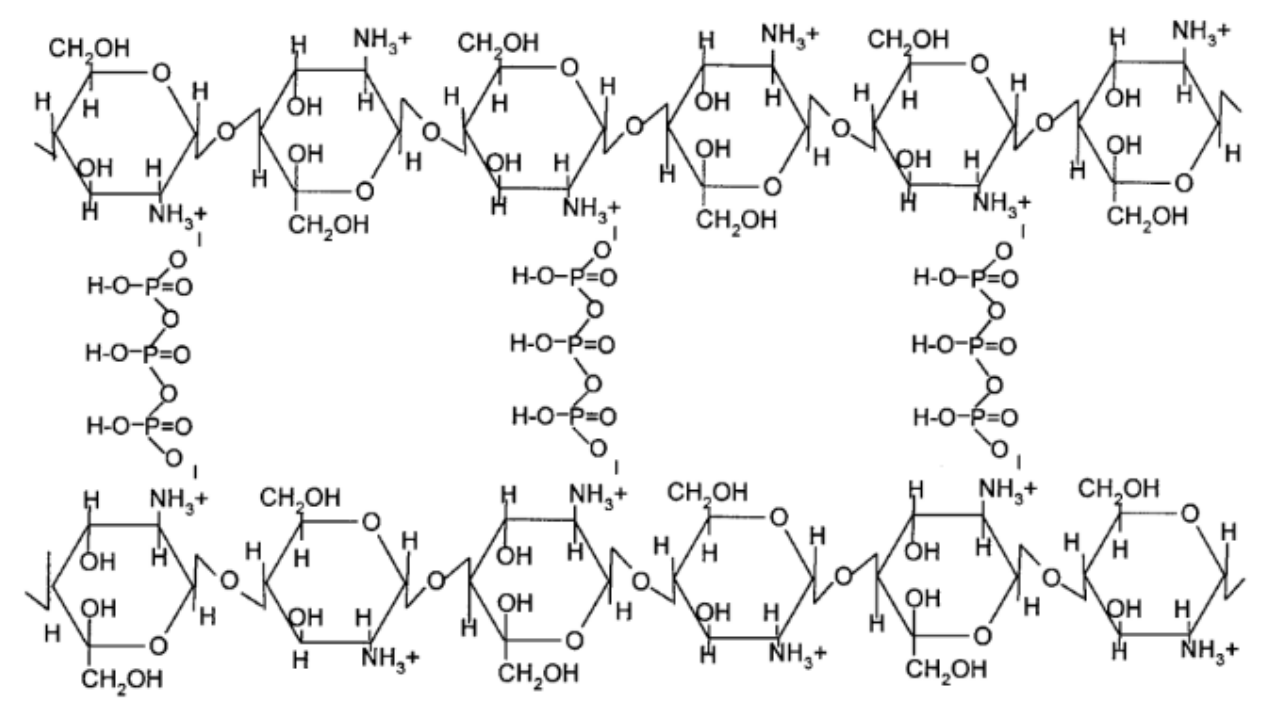

Gambar 1. Ikatan silang kitosan-NaTPP (Mi, et al., 1999)

Nanoherbal ekstrak etanol kayu secang hasil sintesis berupa cairan koloidal berwarna kuning keemasan seperti pada Gambar 2.

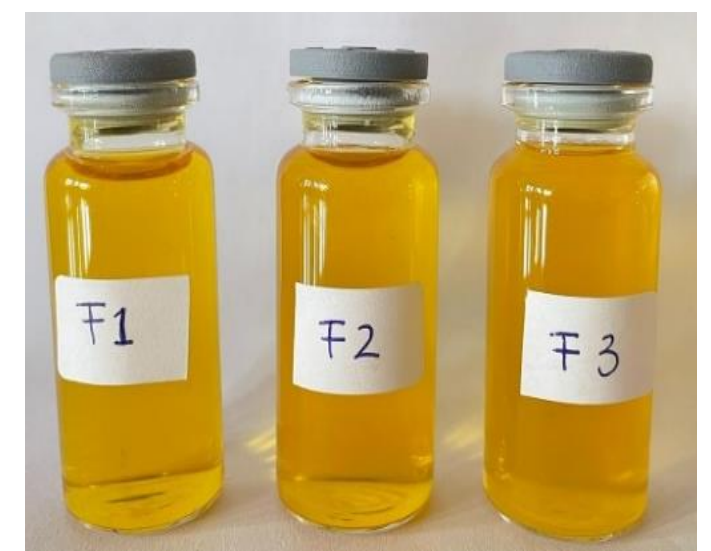

Gambar 2. Nanoherbal ekstrak etanol kayu secang hasil sintesis
Karakterisasi Nanoherbal

1) Ukuran Partikel

Ukuran partikel nanoherbal ekstrak etanol kayu secang hasil sintesis ditentukan dengan zetasizer nano. Tujuan dari karakterisasi ini untuk menentukan ukuran partikel nanoherbal serta menentukan apakah nanoherbal hasil sintesis memenuhi syarat sebagai nanopartikel yaitu memiliki diameter ratarata 1-1000 nm (Buzea, et al., 2007; Mohanraj \& Chen, 2006). Hasil uji menunjukkan bahwa rata-rata ukuran partikel dari ketiga formula nanoherbal ekstrak etanol kayu secang yang diperoleh F1, F2 dan F3 masing-masing sebesar 900,8; 1475,2; dan $2438 \mathrm{~nm}$. Menurut Mohanraj \& Chen (2006), formula yang memenuhi persyaratan sebagai 
nanopartikel yaitu F1 karena memiliki ukuran partikel di bawah $1000 \mathrm{~nm}$. Hal ini sesuai dengan penelitian Husniati dan Oktarina (2014) bahwa kitosan dalam larutan asam asetat akan menghasilkan ukuran partikel dengan rata-rata sebesar 780-940 nm (Husniati \& Oktarina, 2014).

Dari hasil tersebut dapat diketahui bahwa perbandingan konsentrasi kitosan dan Na-TPP mempengaruhi ukuran partikel yang dihasilkan. Hal ini sesuai dengan penelitian Ayumi (2018) bahwa ukuran partikel akan bertambah seiring bertambahnya rasio konsentrasi kitosan terhadap Na-TPP.

\section{2) Potensial Zeta}

Harga potensial zeta ditentukan untuk memprediksi stabilitas larutan koloid karena gaya tolak menolak antar partikel dipengaruhi oleh perbedaan muatan antar partikel. Nilai potensial zeta dihasilkan dari adanya beda potensial antara muatan listrik pada stern layer dengan difuse layer dari partikel koloid. Harga potensial zeta melebihi dari $\pm 30 \mathrm{mV}$ menandakan bahwa koloid nanoherbal yang terbentuk stabil (Akhtar, et al., 2012).

Hasil uji menunjukkan bahwa rata-rata potensial zeta dari ketiga formula nanoherbal ekstrak etanol kayu secang yang diperoleh F1, F2, dan F3 berturutturut yaitu $+529,6 \mathrm{mV},+523,6 \mathrm{mV}$, dan $+546,3 \mathrm{mV}$. Ketiga formula memiliki harga potensial zeta lebih dari $+30 \mathrm{mV}$ sehingga stabilitasnya tinggi karena memiliki gaya untuk mencegah terjadinya aglomerasi partikel. Ketiga formula nanoherbal hasil sintesis memiliki sifat yang stabil atau tidak mudah mengalami aglomerasi atau flokulasi sehingga tidak mudah mengendap (Murdock, et al., 2008).

\section{3) Gugus Fungsi}

Karakterisasi gugus fungsi ditentukan untuk memprediksi interaksi antara kitosan dengan Na-TPP dan ekstrak etanol kayu secang. Pada karakterisasi gugus fungsi ini hanya digunakan nanoherbal ekstrak etanol kayu secang F1 dikarenakan ukuran partikel yang memenuhi standar partikel nano yaitu $F 1$ dengan rata-rata ukuran partikel 900,8 nm.

Sebelum dikarakterisasi, nanoherbal ekstrak etanol kayu secang yang awalnya berbentuk koloidal dikeringkan dengan freezedryer terlebih dahulu selama 8 jam hingga didapatkan nanoherbal ekstrak etanol kayu secang padat berwarna merah tua.

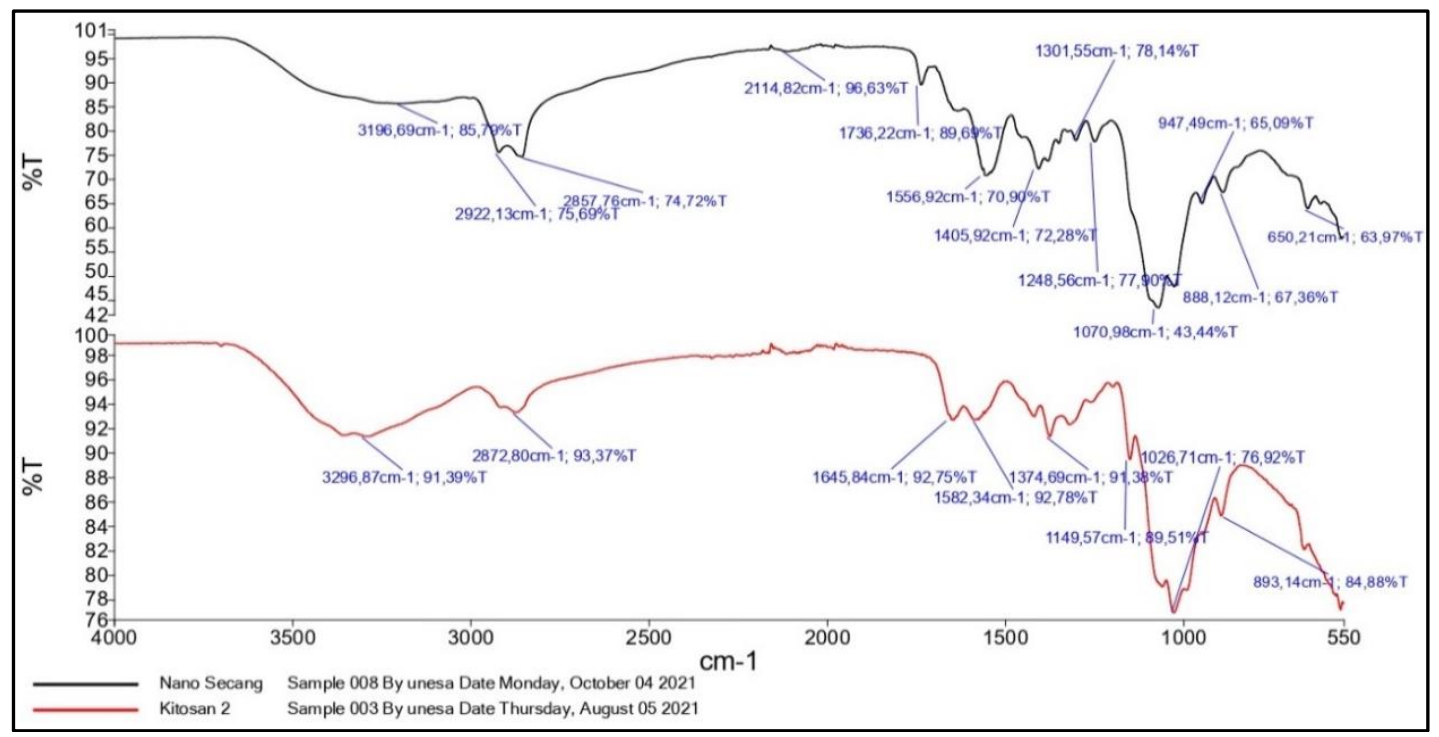

Gambar 3. Spektra IR (a) Nanoherbal ekstrak etanol kayu secang; (b) Kitosan 
Gambar 3 menyatakan bahwa telah terbentuk nanoherbal ekstrak etanol kayu secang yang disintesis dengan metode gelasi ionik. Hal ini ditunjukkan oleh terjadinya pergeseran bilangan gelombang vibrasi ulur gugus $\mathrm{O}-\mathrm{H}$, vibrasi tekuk gugus $\mathrm{N}-\mathrm{H}$, serta munculnya puncak baru dari vibrasi gugus fosfat $(\mathrm{P}=\mathrm{O})$. Vibrasi ulur gugus $\mathrm{O}-\mathrm{H}$ dalam kitosan mengalami pergeseran dari $3297 \mathrm{~cm}^{-1}$ menjadi 3197 $\mathrm{cm}^{-1}$ dalam nanoherbal ekstrak etanol kayu secang. Hal tersebut disebabkan oleh terjadinya interaksi antara gugus $-\mathrm{OH}$ dalam kitosan dengan gugus $-\mathrm{OH}$ fenolik dari senyawa fenolik dalam ekstrak etanol kayu secang. Vibrasi tekuk gugus $\mathrm{N}-\mathrm{H}$ dalam kitosan mengalami pergeseran dari $1582 \mathrm{~cm}^{-1}$ menjadi $1557 \mathrm{~cm}^{-1}$ dalam nanoherbal ekstrak etanol kayu secang. Hal tersebut disebabkan oleh terjadinya ikatan silang antara gugus $\mathrm{NH}_{2}$ kitosan dengan Na-TPP serta interaksi dengan gugus $-\mathrm{OH}$ fenolik dari senyawa fenolik

\section{Daftar Pustaka}

Akhtar, F., Rizvi, M. M. A. \& Kar, S. K., 2012. Oral Delivery of Curcumin Bound to Chitosan Nanoparticles Cured Plasmodium yoelii Infected Mice. Biotechnology Advances, 30(1), pp. 310-320.

Ardila, A., Chairani, I., Nurdiati, N. \& Fitriyah, N. H., 2017. Fabrikasi Nanopartikel Herbal dalam Tablet Effervescent Menggunakan Metode Solvent Emulsificassion Diffusion High Speed Homogenizer. Seminar Nasional Sains dan Teknologi, pp. 18.

Ayumi, D., S. \& M., 2018. Pembuatan dan Karakterisasi Nanopartikel Ekstrak Etanol Daun Ekor Naga (Rhaphidophora pinnata (L.f.) Schott) Menggunakan Metode Gelasi Ionik. Tropical Medicine Conference, Volume 1, pp. 29-33.

Buzea, C., Pacheco, I. I. \& Robbie, K., 2007. Nanomaterials and Nanoparticles: Sources and Toxicity. Biointerphases 2, 2(4), pp. MR17-71. dalam ekstrak etanol kayu secang. Munculnya puncak vibrasi gugus fosfat pada bilangan gelombang $1071 \mathrm{~cm}^{-1}$ dalam nanoherbal ekstrak etanol kayu secang menunjukkan telah terjadi ikatan silang (crosslinking) antara kitosan dengan gugus fosfat dalam Na-TPP (Putri, et al., 2018).

\section{Kesimpulan}

Pembuatan nanoherbal ekstrak etanol kayu secang yang dilakukan dengan metode gelasi ionik memberikan hasil terbaik pada perbandingan kitosan dan $\mathrm{Na}$ TPP 0,5\% : 0,5\% (F1). Nanoherbal yang terbentuk pada perbandingan ini memiliki ukuran rata-rata nanoherbal sebesar 900,8 $\mathrm{nm}$ dan potensial zeta $+529,6 \mathrm{mV}$. Pergeseran bilangan gelombang vibrasi ulur gugus $\mathrm{O}-\mathrm{H}$, vibrasi tekuk gugus $\mathrm{N}-\mathrm{H}$, serta munculnya puncak baru dari vibrasi gugus fosfat $(\mathrm{P}=\mathrm{O})$, mendukung terbentuknya nanoherbal.

Husniati \& Oktarina, E., 2014. Sintesis Nano Partikel Kitosan dan Pengaruhnya Terhadap Inhibisi Bakteri Pembusuk Jus Nanas. Jurnal Dinamika Penelitian Industri, 25(2), pp. 89-95.

Kaban, J., Bangun, H. D. \& Asteria, K. D., 2006. Pembuatan Membran Kompleks Polielektrolit Alginat Kitosan. Jurnal Sains Kimia, 10(1), pp. 10-16.

Kusmiati, D. \& Priadi, D., 2014. Analisa Senyawa Aktif Ekstrak Kayu Secang (Caesalpinia sappan L.) Yang Berpotensi Sebagai Antimikroba. Seminar Nasional Teknologi Industri Hijau, Volume 1, pp. 169-174.

Luntungan, A. H., Mandey, L. C., Rumengan, I. F. M. \& Suptijah, P., 2017. Pengaruh Penyalutan Nanokitosan Pada Kandungan Fenolik Ekstrak Daun Kemangi (Ocimum basilicum L.). Jurnal Ilmu dan Teknologi Pangan, 5(2), pp. 2025 . 
Mardliyanti, E., Muttaqien, S. E. \& Setyawati, D. R., 2012. Sintesis Nanopartikel Kitosan-Tripoly Phosphate Dengan Metode Gelasi Ionik: Pengaruh Konsentrasi dan Rasio Volume Terhadap Karakteristik Partikel. Prosiding Pertemuan Ilmiah Ilmu Pengetahuan dan Teknologi Bahan 2012, Issue 90, p. 93.

Martien, R. et al., 2012. Perkembangan Teknologi Nanopartikel Sebagai Sistem Penghantaran Obat. Majalah Farmaseutik, 8(1), pp. 133-144.

Mi, F.-L., Shyu, S.-S., Lee, S.-T. \& Wong, T.-B., 1999. Kinetic Study of Chitosan-Tripolyphosphate Complex Reaction and Acid-Resistive Properties of the ChitosanTripolyphosphate Gel Beads Prepared by in-Liquid Curing Method. Journal of Polymer Science, Volume 37, pp. 1551-1564.

Mohanraj, V. J. \& Chen, Y., 2006. Nanoparticles - A Review. Tropical Journal of Pharmaceutical Research, 5(1), pp. 561-573.

Murdock, R. C. et al., 2008. Characterization of Nanomaterial Dispersion in Solution Prior to In Vitro Exposure Using Dynamic Light Scattering Technique. Toxicological Sciences, 101(2), pp. 239-253.

Pakki, E. et al., 2016. Formulasi Nanopartikel Ekstrak Bawang Dayak (Eleutherine americana (Aubl) Merr) dengan Variasi Konsentrasi KitosanTripolifosfat (TPP). J. Trop. Pharm. Chem., 3(4), pp. 251-263.

Park, K. \& Yeo, Y., 2007. Microencapsulation Technology. In: Encyclopedia of Pharmaceutical Technology. New York: Informa Healthcare USA, pp. 2315-2327.

Putri, A. I., Sundaryono, A. \& Candra, I. N., 2018. Karakterisasi Nanopartikel Kitosan Ekstrak Daun Ubijalar (Ipomoea batatas L.) Menggunakan Metode Gelasi Ionik. Jurnal Pendidikan dan Ilmu Kimia, 2(2), pp. 203-207.
Rina, O., 2013. Identifikasi Senyawa Aktif dalam Ekstrak Etanol Kayu Secang (Caesalpinia sappan L.). Prosiding Semirata FMIPA Universitas Lampung, pp. 215-218.

Rismana, E. et al., 2013. Pengujian Stabilitas Sediaan Antiacne Berbahan Baku Aktif Nanopartikel Kitosan Ekstrak Manggis - Pegagan. Buletin Penelitian Kesehatan, 41(4), pp. 207216.

Shu, X. Z. \& Zhu, K. J., 2002. Controlled Drug Release Properties of Ionically Cross-linked Chitosan Beads: The Influence of Anion Structure. International Journal of Pharmaceutics, 233(1-2), pp. 217255.

Sugiyanto, R. N., Putri, S. R., Damanik, F. S. \& Sasmita, G. M. A., 2013. Aplikasi Kayu Secang (Caesalpinia sappan L.) dalam Upaya Prevensi Kerusakan DNA Akibat Paparan Zat Potensial Karsinogenik melalui MNPCE Assay. Prosiding Pekan Ilmiah Mahasiswa Nasional Program Kreativitas Mahasiswa, pp. 1-6.

Syarmalina, Wirawan, D. \& Rahmat, D., 2019. Formulasi Nanopartikel Ekstrak Temulawak Berbasis Kitosan Sebagai Antijerawat. Medical Sains, 3(2), pp. 153-158. 